\title{
50th anniversary of KITLV-Jakarta a short overview
}

The KITLV-Jakarta office was founded fifty years ago, as a result of discussions between Professor Teeuw and Professor Koentjaraningrat to increase academic cooperation between the Netherlands and Indonesia. The two countries were on the point of signing a cultural agreement. The office was initially accommodated on the premises of the Indonesian Institute of Sciences, LIPI (Lembaga Ilmu Pengetahuan Indonesia), which had been established just the year before in 1968 .

The Jakarta office was a branch of the KITLV (Koninklijk Instituut voor Taal-, Land- en Volkenkunde), which was established in the Netherlands in 1851. Initially its English translation was the Royal Institute for Linguistics and Anthropology, but in 2003 this was changed to the Royal Netherlands Institute of Southeast Asian and Caribbean Studies.

When the Jakarta office was founded in 1969, the KITLV institute in the Netherlands could already boast a long and rich history. The Institute had since its beginning a threefold mission, namely the development and management of collections, research, and academic publishing, mainly on Indonesia and the "Dutch" Caribbean. How these activities were implemented, and how the Institute changed and was governed throughout this time can be read in the very extensive 150th anniversary history written by Maarten Kuitenbrouwer (2001, Tussen oriëntalisme en wetenschap; Koninklijk Instituut voor Taal-, Land-en Volkenkunde in historisch verband 1851-2001; Leiden: KITLV Press).

The main activities of the Jakarta office were initially in line with that of the head office in the Netherlands: academic cooperation, acquisition, and publishing. In the beginning, the Jakarta office was managed by two directors: J.J. Ras for academic cooperation, and A.C.M. Peeters for acquisition and documentation activities. Ras was subsequently succeeded by J.W. Minderhout, and Peeters by M.H. Dol. Around 1975 they were respectively followed up by A.C. van der Leeden and Jaap Erkelens. In 1977, after Van der Leeden had stepped down, the two functions were merged and Erkelens became the sole representative.

In 2001 the KITLV in the Netherlands came, as one of many academic institutions, under the governance of the Royal Netherlands Academy of Arts and Sciences, KNAW. The KITLV-Jakarta office automatically followed suit. In 2014, due to a reorganization and financial restructuring at the umbrella organization KNAW, it was decided that the KITLV collections, which were in fact owned by the KITLV Learned Society (Vereniging KITLV), would be transferred to the Leiden University Libraries.

As a consequence, the governance of the KITLV-Jakarta office also transferred to Leiden University in 2014. At that time the Jakarta office was managed by Roger Tol, who had succeeded Jaap Erkelens in 2003. The future of 
the Jakarta office being secured, Tol moved the office from the residential area of Prapanca in South Jakarta to the premises of the Embassy of the Kingdom of the Netherlands. I succeeded Tol in 2015 after his retirement, adding a new function to the Jakarta office. It now doubled also as the representative office of Leiden University in Indonesia, focusing on increasing research cooperation between Leiden and Indonesian universities and research institutes. In this way the original dual function of the Jakarta office, when it was established in 1969, was effectively restored.

I am very pleased that this year we can celebrate our 50th anniversary with the support of LIPI and Wacana, Journal of the Humanities of Indonesia, by organizing an International Seminar on "Indonesian heritage and library collections" on 25 June 2019 at LIPI in Jakarta. On this occasion Wacana, as the international peer-reviewed and Scopus-indexed journal of the Faculty of Humanities, Universitas Indonesia, is launching a special issue on that theme. I am especially indebted to Sadiah Boonstra, Susi Moeimam, and the team at Wacana for making this possible.

I am confident that in the future KITLV-Jakarta, also as the representative office of Leiden University, will play an important role in the academic cooperation between Indonesia and the Netherlands and in increasing the mutual accessibility of the Indonesian collections.

Marrik Bellen

Director of KITLV-Jakarta and Office of Leiden University in Indonesia 